\title{
Cadherin-2 Staining Method
}

National Cancer Institute

\section{Source}

National Cancer Institute. Cadherin-2 Staining Method. NCI Thesaurus. Code C122854.

An immunohistochemical technique used to detect the presence of cadherin-2 ( $\mathrm{N}$ cadherin) in a tissue sample. 